\title{
Signalling pathways involved in the control of sperm cell volume
}

\author{
A M Petrunkina, R A P Harrison ${ }^{1}$, M Tsolova ${ }^{2}$, E Jebe $^{2}$ and E Töpfer-Petersen ${ }^{2}$ \\ Unit for Reproductive Medicine of Clinics, Clinic for Horses, University of Veterinary Medicine Hannover Foundation, \\ Bünteweg 15, 30559 Hannover, Germany, ${ }^{1} 11$ London Road, Great Shelford, Cambridge, CB2 5DB, UK and ${ }^{2}$ School \\ of Veterinary Medicine Hannover Foundation, Institute for Reproductive Biology, Bünteweg 15, 30559 Hannover, \\ Germany
}

Correspondence should be addressed to A M Petrunkina; Email: anna.petrunkina@tiho-hannover.de

\begin{abstract}
The ability to maintain cellular volume is an important general physiological function, which is achieved by specific molecular mechanisms. Hypotonically induced swelling results in the opening of $\mathrm{K}^{+}$and $\mathrm{Cl}^{-}$ion channels, through which these ions exit with accompanying water loss. This process is known as regulatory volume decrease (RVD). The molecular mechanisms that control the opening of the ion channels in spermatozoa are as yet poorly understood. The present study investigated pathways of osmo-signalling using boar spermatozoa as a model. Spermatozoa were diluted into isotonic and hypotonic Hepes-buffered saline in the presence or absence of effector drugs, and at predetermined intervals volume measurements were performed electronically. Treatment with protein kinase C (PKC) inhibitors staurosporine, bismaleimide I and bismaleimide X led to dosedependent increases of both isotonic and hypotonic volumes $(P<0.05)$. However, as the isotonic volume was affected more than the hypotonic volume, the kinase inhibitors appeared to improve RVD, whereas activation of PKC with phorbol dibutyrate blocked RVD. The increase in isotonic cell volume induced by bismaleimide $X$ was observed in chloride-containing medium but not in the medium in which chloride was replaced by sulphate, implying that PKC was involved in the control of chloride channel activity, e.g. by closing the channel after volume adjustment. The protein phosphatase PP1/PP2 inhibitors calyculin and okadaic acid increased the isotonic volume only slightly but they greatly increased the relative cell volume and blocked RVD. The activation of RVD processes was found to be cAMP-dependent; incubation with forskolin and papaverine improved volume regulation. Moreover, papaverine was able to overcome the negative effect of protein phosphatase inhibitors. The mechanism of sperm RVD appears to involve (a) alterations in protein phosphorylation/dephosphorylation balance brought about by PKC and PP1 and (b) a cAMP-dependent activating pathway.

Reproduction (2007) 133 61-73
\end{abstract}

\section{Introduction}

When cells encounter hypo- or hypertonic environments, they tend to swell or shrink due to the influx or efflux of water during re-establishment of osmotic equilibrium. Various animal cell types are able to maintain their volume after osmotic shock, thereby avoiding the consequences of excessive volume changes (Lang et al. 1998). During its life, the spermatozoon experiences considerable changes in its environment, most notably during maturation within the epididymis and at ejaculation (Yeung et al. 2004a and references therein). To be able to maintain cellular functionality in face of these osmotic changes, spermatozoa of several mammalian species (boar, mouse, bull and human) have been found to exhibit volume regulatory abilities, particularly regulatory volume decrease (RVD) in response to hypotonic challenge (Petrunkina et al. 2004a, and references therein).
It has been reported for a variety of cell types that the activation of independent $\mathrm{K}^{+}$and $\mathrm{Cl}^{-}$channels is swellingsensitive, as is that of organic osmolyte channels (Lang etal. 1998). Similar swelling-dependent activation of these channels has been demonstrated for spermatozoa of a variety of species, such as cattle, swine, human and dog (Kulkarni et al. 1997, Yeung et al. 2003, Petrunkina et al. 2001a, 2004a, 2004b). In somatic cells, RVD mediated by chloride and potassium currents is known to involve signalling cascades mediated by protein phosphorylation and dephosphorylation (Klein et al. 1993, Bize \& Dunham 1994, Robson \& Hunter 1994, 1997, Crepel et al. 1998, Musch et al. 1998, Voets et al. 1998, Thoroed et al. 1999, Hubert et al. 2000). In contrast, very little is known about whether phosphorylation processes are linked to the activation of osmo-sensing regulatory mechanisms in spermatozoa. Yeung et al. (1999, 2000) have hypothesized 
that the ability to regulate volume is important for achieving fertility and that tyrosine phosphorylation may be involved in RVD. Sperm from c-ros tyrosine kinase receptor knockout mice were infertile and showed impaired motility and other characteristics commensurate with a volume regulatory disturbance (though, as pointed out by the authors (Yeung et al. 2004b), these changes may have been due to an effect of c-ros knockout on the epididymis itself and thence disturbance of the maturation process). In domestic species (bull, boar and dog), it has been demonstrated that the control of sperm cell volume is closely related to the sperm's ability to bind to the oviductal epithelium, and/or to their fertility competence in vivo; volumetric behaviour is also a crucial parameter for evaluating effects of cryoprotectiva (Petrunkina et al. 2001b, 2004a, 2005a, Khalil et al. 2006).

Initial pharmacological and molecular evidence suggests that regulation of sperm cell volume under hypertonic conditions is mediated by protein tyrosine kinase (PTK)-dependent pathways (Petrunkina et al. 2005b). In that study, differential effects of the PTK inhibitor lavendustin and the general protein kinase inhibitor staurosporine (especially potent against protein kinase C, PKC) were observed, suggesting that phosphorylation reactions mediated by PTKs and/or by serinethreonine kinases such as the PKCs may play a major role in volume regulation of mammalian sperm. Thus far, there has not been any investigation of a putative role for CAMP in the control of cell volume. This study is the first seeking to carry out a comparative investigation of the roles of CAMP, the protein kinases PKA, PKC and PTK, and the protein phosphatases PP1, PP2A and TP (tyrosine phosphatase) in volume control in mammalian spermatozoa, under both isotonic and hypotonic conditions.

Our study was based upon the boar sperm model and used electronic cell sizing to detect volume responses. Commonly used techniques such as protein profiling in sperm extracts revealed by Western blotting may be helpful in detecting and identifying the proteins likely to be involved in the mediation of cellular functions. However, these techniques neither allow characterization of the cell function in its physiological environment nor allow singlecell-based analysis: an appropriate screening of signalling pathways at the cellular level must be completed prior to performing focused studies at the molecular level. In the last decade, flow cytometry has been widely used to characterize sperm volumetric behaviour (Yeung et al. 2003, 2004a, 2005a, 2005b); although this technique is obviously more advantageous for functional studies on cell physiology, it allows only relative quantification of the cell volume; it is also greatly dependent on instrument settings. Volume analysis by electronic cell sizing, on the other hand, as well as providing single-cell information, allows exact calibration for cell volume quantification in physical units (Petrunkina etal. 2004a, 2004c). Moreover, the subtle changes in cell volume due to osmo-sensing are often below the threshold at which they can be detected by flow cytometry; such a drawback is especially critical for studies on spermatozoa (Petrunkina et al. 2004b, 2005a, 2005b). In our study, therefore, we have used electronic cell sizing to enable accurate and sensitive monitoring of osmotically and pharmacologically induced changes in sperm volume.

\section{Materials and Methods}

\section{Chemicals}

Unless otherwise stated, chemicals were obtained from Merck AG (Darmstadt, Germany), Alexis GmbH (Grünberg, Germany), Merck KgaA (Calbiochem, Darmstadt, Germany) and Sigma AG (Sigma-Aldrich).

\section{Semen sources}

Semen was obtained from boars of fertile crossbred animals from the Institute of Reproductive Medicine's boar colony. These samples were collected (generally twice a week) by the so-called gloved hand method via a sterile gauze (to remove gel). Immediately after collection, the semen was transferred to the laboratory and diluted in Beltsville thawing solution (BTS) extender (Johnson et al. 1988) to a concentration of between 0.8 and $1.0 \times 10^{8} \mathrm{cell} / \mathrm{s} / \mathrm{ml}$, and stored at $17^{\circ} \mathrm{C}$. Semen samples stored up to $72 \mathrm{~h}$ were used. In some experimental series, semen samples diluted in Androhep (Waberski et al. 1994) were also used.

The initial quality of ejaculates (volume, concentration, motility and morphology) was investigated as described by Weitze (2001). The minimal requirements for boar sperm quality were set according to the following criteria: semen volume $100 \mathrm{ml}$; sperm concentration $0.1 \times 10^{6}$ per $\mu \mathrm{l}$; motility $70 \%$; the total proportion of morphological alterations including plasma droplets $45 \%$; the proportion of sperm with attached plasma droplets $<25 \%$ (Weitze 2001). Only ejaculates which fulfilled the minimal requirements of boar sperm quality were subject to further experiments.

Just before experimentation, aliquots of diluted semen (3-5 ml) were washed through a two-step gradient of 35 and $70 \%$ isotonic Percoll-saline (Harrison et al. 1993). After removal of the supernatant layers, the loose sperm pellet was resuspended in residual $70 \%$ Percoll to a final concentration of about $2 \times 10^{8}$ cells $/ \mathrm{ml}$. Semen samples were maintained throughout this procedure at a minimum of $25^{\circ} \mathrm{C}$, and processed samples were used within $1 \mathrm{~h}$.

\section{Media}

Two variants of a Hepes-buffered saline medium (HBS) were used as the vehicles for experimentation. The isotonic variant (isoHBS; $300 \mathrm{mosmol} / \mathrm{kg}$ ) consisted of $137 \mathrm{mmol} / \mathrm{l} \mathrm{NaCl}, 10 \mathrm{mmol} / \mathrm{l}$ glucose, $2.5 \mathrm{mmol} / \mathrm{l} \mathrm{KOH}$ and $20 \mathrm{mmol} / \mathrm{l}$ Hepes buffered with $\mathrm{NaOH}$ to $\mathrm{pH} 7.4$ at 
$39^{\circ} \mathrm{C}$. The hypotonic variant (hypoHBS; $180 \mathrm{mosmol} / \mathrm{kg}$ ) was prepared by adjusting the $\mathrm{NaCl}$ content to approximately $76 \mathrm{mmol} / \mathrm{l}$ (Petrunkina et al. 2004a).

The isotonic medium based on sodium sulfate instead of sodium chloride was used for substitution experiments (Petrunkina et al. 2004a, 2005b). This medium (isoSulf, $300 \mathrm{mosmol} / \mathrm{kg}$ ) consisted of $115 \mathrm{mmol} / \mathrm{l}$ sodium sulfate, $10 \mathrm{mmol} / \mathrm{l}$ glucose, $20 \mathrm{mmol} / \mathrm{l}$ Hepes buffered with $\mathrm{NaOH}$ to $\mathrm{pH} 7.4$ at $39^{\circ} \mathrm{C}$. To minimize the detection of particulate noise during cell volume measurements, all media were passed through a $0.2 \mu \mathrm{m}$ filter before use.

\section{Experimental procedure}

In essence, the experimental approach consisted of diluting washed sperm samples at $39{ }^{\circ} \mathrm{C}$ in iso- or hypotonic medium containing specific effectors, and then taking subsamples at timed intervals for analysis of the population volume distributions. Effects were largely judged by comparing the modal volumes of such distributions. The pharmaceuticals, their effects and the ranges of concentration used are given in Table 1.

The general experimental procedure was as follows: aliquots of washed sperm samples were diluted in $1 \mathrm{ml}$ volumes of isoHBS at $39^{\circ} \mathrm{C}$ containing predetermined concentrations of effectors (final sperm cell concentration between 0.5 and $1 \times 10^{7} \mathrm{ml}^{-1}$ ). After 10-min preincubation, samples were transferred to $5 \mathrm{ml}$ of either hypoHBS or isoHBS containing the same concentration of effector as the parent medium, and incubated further at $39^{\circ} \mathrm{C}$ (final sperm concentration about $1 \times 10^{5}$ cells $/ \mathrm{ml}$ ). The isotonic and hypotonic sperm suspensions were

Table 1 Effectors used in this study.

\begin{tabular}{|c|c|c|c|c|}
\hline Compound & Abbreviation & Established effects & $\begin{array}{l}\text { Range } \\
\text { tested }\end{array}$ & $\begin{array}{l}\text { Previously detected effects on sperm } \\
\text { function }\end{array}$ \\
\hline Staurosporine & Sta & $\begin{array}{l}\text { Inhibits protein kinase } \mathrm{C}\left(\mathrm{IC}_{50}=0.7 \mathrm{nM}\right) \text {, } \\
\text { protein kinase } \mathrm{A}\left(\mathrm{IC}_{50}=7 \mathrm{nM}\right) \text {, protein } \\
\text { kinase } \mathrm{G}\left(\mathrm{IC} \mathrm{C}_{50}=8.5 \mathrm{nM}\right), \mathrm{CaM} \text { kinase } \\
\left(\mathrm{IC}_{50}=20 \mathrm{nM}\right)\end{array}$ & $0.1-1 \mu \mathrm{M}$ & $\begin{array}{l}0.1-2 \mu \mathrm{M} \text { inhibits } \mathrm{ZP}-\text { induced } \mathrm{AR}^{\mathrm{a}} \\
\text { and } 1-10 \mu \mathrm{M} \text { inhibits increase in } \\
\text { merocyanine binding due to } \\
\text { bicarbonate }^{\mathrm{b}}\end{array}$ \\
\hline $\begin{array}{l}N \text {-[2-((p-Bromocinnamyl)amin) ethyl]-5- } \\
\text { isoquinolinesulfonamide }\end{array}$ & $\mathrm{H}-89$ & $\begin{array}{l}\text { Inhibits protein kinase } \mathrm{A}\left(K_{\mathrm{i}}=48 \mathrm{nM}\right) \text { and } \\
\text { other kinases at high concentrations: } \mathrm{PKC} \\
\left(K_{\mathrm{i}}=32 \mu \mathrm{M}\right)\end{array}$ & $5-15 \mu \mathrm{M}$ & $\begin{array}{l}10-50 \mu \mathrm{M} \text { inhibits increase in } \\
\text { merocyanine binding }\end{array}$ \\
\hline $\begin{array}{l}\text { Bisindolylmaleimide I, GF-109203x (2-[1- } \\
\text { (3-dimethylaminopropyl)-1H-indol-3-yl]- } \\
\text { 3-(1h-indol-3-yl)-maleimide) }\end{array}$ & Bis I & $\begin{array}{l}\text { Inhibits protein kinase } C \text { with improved } \\
\text { selectivity as compared to staurosporine } \\
\left(K_{\mathrm{i}}=10 \mathrm{nM}\right) \text { and protein kinase } \mathrm{A} \\
(>2 \mu \mathrm{M})\end{array}$ & $1-5 \mu \mathrm{M}$ & $\begin{array}{l}100 \mathrm{nM} \text { decreases calcium influx and } \\
\text { acrosome reaction }^{\mathrm{c}}\end{array}$ \\
\hline $\begin{array}{l}\text { Bisindolylmaleimide X 2-(8-aminomethyl- } \\
\text { 6,7,8,9-tetrahydropyrido[1,2- a]indol-3- } \\
\text { yl)-3-(1-methylindol-3-yl)maleimide }\end{array}$ & Bis $X$ & Selective inhibitor of PKC $\left(\mathrm{IC}_{50}=15 \mathrm{nM}\right)$ & $0.3-3 \mu \mathrm{M}$ & \\
\hline $\begin{array}{l}\text { Bisindolylmaleimide } \mathrm{V} \text {, ([2, 3-bis }(1 \mathrm{H}- \\
\text { indol-3-yl)- } N \text {-methylmaleimide }]\end{array}$ & Bis $V$ & Negative control for Bis $\mathrm{X}\left(\mathrm{IC}_{50}>100 \mu \mathrm{M}\right)$ & $0.3-3 \mu \mathrm{M}$ & \\
\hline Phorbol-12,13-dibutyrate & PDBu & Activates protein kinase $\mathrm{C}$ & $0.3-3 \mu \mathrm{M}$ & \\
\hline $\begin{array}{l}4 \alpha \text {-Phorbol }(4 \alpha, 9 \alpha, 12 \beta, 13 \alpha, 20 \text {-penta- } \\
\text { hydroxytiglia-1,6-dien-3-one) }\end{array}$ & $\alpha-\mathrm{PDBu}$ & Negative control for PDBu & $0.3-3 \mu \mathrm{M}$ & \\
\hline $\begin{array}{l}\text { Forskolin ( } 7 \beta \text {-Acetoxy-8,13-epoxy- } 1 \alpha, 6 \beta, \\
9 \alpha \text {-trihydroxy-labd- } 14 \text { en-11-one) }\end{array}$ & Forskolin & $\begin{array}{l}\text { Activates adenylate cyclase }\left(\mathrm{EC}_{50}=4 \mu \mathrm{M}\right) \text {, } \\
\text { leading to elevated cAMP levels }\end{array}$ & $1-10 \mu \mathrm{M}$ & $\begin{array}{l}10 \mu \mathrm{M} \text { increases sperm cAMP levels }{ }^{\mathrm{d}} \text {; } \\
100 \mu \mathrm{M} \text { increases sperm capacitation } \\
\text { rates \& phosphorylation }\end{array}$ \\
\hline $\begin{array}{l}\text { 1,9-Dideoxyforskolin ( } 7 \beta \text {-Acetoxy- } 6 \beta \text { - } \\
\text { hydroxy- } 8,13 \text { - epoxy-labd- } 14 \text { en- } 11 \text {-one) }\end{array}$ & DDFSK & $\begin{array}{l}\text { Does not activate adenylate cyclase. } \\
\text { Inhibits chloride channels }\end{array}$ & $1-10 \mu \mathrm{M}$ & $\begin{array}{l}1 \mu \mathrm{M} \text { inhibits regulatory volume } \\
\text { decrease }^{f}\end{array}$ \\
\hline $\begin{array}{l}\text { Papaverine 6,7-dimethoxy-1-veratryliso- } \\
\text { quinoline hydrochloride }\end{array}$ & Pap & Inhibitor of cAMP phosphodiesterase & $20 \mu \mathrm{M}$ & $\begin{array}{l}20 \mu \mathrm{M} \text { enhances merocyanine bind- } \\
\text { ing in the presence of PP inhibitors }{ }^{\mathrm{b}} \text {; } \\
\text { enhances iso- and hypertonic volume }\end{array}$ \\
\hline $\begin{array}{l}\text { Lavendustin A 5-[[2,5-dihydroxy- } \\
\text { phenyl)methyl][(2-hydroxy-phenyl)- } \\
\text { methyl]amino]-2-hydroxybenzoic acid }\end{array}$ & Lav A & $\begin{array}{l}\text { Potent inhibitor of the protein tyrosine } \\
\text { kinases EGFR kinase and p60c-src } \\
\left(\mathrm{IC}_{50}=11 \mathrm{nM} \text { and } 500 \mathrm{nM}\right) \text {. Does not } \\
\text { inhibit PKA or PKC }\end{array}$ & $1-5 \mu \mathrm{M}$ & $\begin{array}{l}1-15 \mu \mathrm{M} \text { enhances isotonic and } \\
\text { hypertonic volume }\end{array}$ \\
\hline Okadaic acid & $\mathrm{OA}$ & $\begin{array}{l}\text { Potent inhibitor of protein phosphatases } \\
\text { PP1 }\left(\mathrm{IC}_{50}=10-15 \mathrm{nM}\right) \text { and PP2A } \\
\left(\mathrm{IC} \mathrm{C}_{50}=0.1 \mathrm{nM}\right) . \text { Does not affect tyrosine } \\
\text { phosphatase activity }\end{array}$ & $10-100 \mathrm{nM}$ & $\begin{array}{l}20-200 \mathrm{nM} \text { enhances merocyanine } \\
\text { binding in the presence of papaverine }\end{array}$ \\
\hline Calyculin & Cal & $\begin{array}{l}\text { Potent inhibitor of PP1 }\left(\mathrm{IC}_{50}=2 \mathrm{nM}\right) \\
\text { and PP2A protein phosphatases } \\
\left(\mathrm{IC}_{50}=0.5-1 \mathrm{nM}\right)\end{array}$ & $10-100 \mathrm{nM}$ & $\begin{array}{l}50 \mathrm{nM} \text { increases motility }{ }^{\mathrm{h}} \text {; if papaver- } \\
\text { ine present, } 20-200 \mathrm{nM} \text { enhances } \\
\text { merocyanine binding }\end{array}$ \\
\hline Sodium orthovanadate & Vanadate & $\begin{array}{l}\text { Inhibitor of protein tyrosine phosphatases } \\
\text { with broad specificity }\end{array}$ & $100 \mu \mathrm{M}$ & \\
\hline
\end{tabular}

a Liu \& Baker (1997). ${ }^{\mathrm{b}}$ Harrison \& Miller (2000). ${ }^{\mathrm{c} C}$ Cordoba \& Beconi (2001). ${ }^{\mathrm{d}}$ Leclerc \& Kopf (1995). ${ }^{\mathrm{e}}$ Leclerc et al. (1996). ${ }^{\mathrm{f}} \mathrm{Petrunkina} \mathrm{et} \mathrm{al.} \mathrm{(2004a).}$ getrunkina et al. (2005b). ${ }^{\mathrm{h}}$ Smith et al. (1996). 
sampled for cell volume measurement after predetermined periods (between 5 and $20 \mathrm{~min}$ ). IsoHBS and hypoHBS without additives were used as controls. When an effector was added from a stock solution prepared in alcohol or DMSO, the final concentration of solvent in the incubation medium was always $<0.5 \%(\mathrm{v} / \mathrm{v})$, a level which had no significant effect on the volumetric behaviour of the spermatozoa under the experimental conditions tested.

\section{Electronic volume analysis}

At each sampling time, a single sample from each incubated sperm suspension was passed through a CASY 1 cell counter (Schaerfe Systems $\mathrm{GmbH}$, Reutlingen, Germany). This instrument produces cell volume information on the basis of cell frequency distribution. During the measurements, the cells suspended in the electrolyte solution pass through a capillary pore. The changes in electric resistance caused by each cell passing through the pore result in voltage changes proportional to the cell volume. Because the measurement signal is registered at a frequency of $1 \mathrm{MHz}$, cell passage produces a series of individual signal pulses; the voltage change characteristics for each cell are calculated by integration of these pulses (pulse area analysis). This methodology guarantees high accuracy and resolution of measurements; the pulse area values are neither dependent on the orientation of the sperm cells as they pass through the capillary pore nor on the geometrical shape of the cells. The recorded electric signals are converted to 'volume equivalent' values using a channel analyser with 512000 volume measurement channels corresponding to the pulse 'areas' produced by each cell. The resultant values are then recalculated to a linear distribution within 1024 effective cell size channels.

In our experiments, the sample volume setting was $200 \mu \mathrm{l}$ and the size scale $10 \mu \mathrm{m}$ (i.e. the system was set to record particles with diameters up to $10 \mu \mathrm{m}$, which corresponds to a volume equivalent value of about $524 \mathrm{fl}$ ); each sampling obtained data from more than 10000 cells so that overall the resolution was approximately $0.1 \mu \mathrm{m}$ per effective size channel.

Because the electrical conductivity of hypoHBS was different from that of isoHBS (due to different concentrations of electrolyte), data recorded from sperm suspensions in the former medium were multiplied by a correction factor to obtain the real physical volume (see Petrunkina \& Töpfer-Petersen 2000). Volume data are presented as real volumes in femtolitres (fl: $10^{-15} \mathrm{I}$ ).

\section{Analysis of volumetric data}

Unless otherwise stated, treatment effects were judged by comparing the modal values of the sample volume distributions, since modal volume is the most sensitive parameter of response to osmotic stress (Petrunkina \&
Töpfer-Petersen 2000). By comparing modal volumes of different particle subpopulations within the sample, it was possible to differentiate between spermatozoa and debris (see Petrunkina et al. 2004a), and only the spermatozoa were considered. (Note that the high degree of differentiation between peaks related to spermatozoa and those related to debris is improved by the Percoll-gradient centrifugation used to prepare the original sperm samples: this leads to large-scale elimination of diluent, free plasma droplets and sperm fragments: Petrunkina et al. 2004b).

The relative volume shift $V_{\mathrm{r}}$ was used as a measure of the volume response to hypotonic conditions. It was defined as $V_{\mathrm{r}}=V_{\text {hypo }} / V_{\text {iso, }}$ where $V_{\text {hypo }}$ is the modal value of the hypotonic volume distribution and $V_{\text {iso }}$ the modal value of the isotonic volume distribution. $V_{r, 5}$ describes the relative volume increase in the face of hypotonic challenge after $5 \mathrm{~min}$ and $V_{\mathrm{r}, 20}$ its change (volume decrease) after $20 \mathrm{~min}$. The RVD was defined as the recovery of the relative hypotonic volume $R V D=V_{r, 20}-$ $V_{r, 5}$. When several peaks appeared within a volume distribution (see Petrunkina et al. 2004b), the volume of the first most abundant osmotically active subpopulation peak was used for the analysis; the subpopulation was considered to be osmotically active when the relative volume shift $V_{\mathrm{r}}=V_{\text {hypo }} / V_{\text {iso }}$ was $>1$, indicating that the spermatozoa within this population were able to swell, thus were alive (Petrunkina \& Töpfer-Petersen 2000).

The absolute cell volumes under both isotonic and hypotonic conditions were compared between the treatments, and the relative volume shifts attributed to the different treatments were compared with those in control samples. The response to effector treatment under isotonic conditions was judged by relating the modal volume of the resultant main peak to that of the sperm peak in the control sample.

\section{Flow cytometric estimation of cell viability}

Sperm samples were labelled for 10 min with propidium iodide ( $\mathrm{Pl}, 5 \mu \mathrm{g} / \mathrm{ml}$ final concentration); this dye binds to DNA in membrane-damaged cells and is now commonly used for recording the membrane integrity (cf. Harrison \& Vickers 1990). The stained samples were analysed with a Dako Galaxy flow cytometer (Dako GmbH, Hamburg, Germany). For each sample, a single measurement was made. The cells were excited at $488 \mathrm{~nm}$ using an argon laser, and propidium iodide fluorescence was detected using a $610 \mathrm{~nm}$ band-pass filter (FL-3) on a logarithmic scale. Forward- and side-scatter data (FSC and SSC) were collected in the linear mode.

For each day's analyses, the control settings were adjusted as follows. An unstained sperm sample was first passed through the instrument. The forward- and sidescatter settings were adjusted so that the sperm population was presented as an L-shaped profile. The fluorescence detector voltages were adjusted after 
measuring the sample stained only with PI so that the dead cells were clearly distinguishable from the live (unstained) cells on the $\mathrm{Y}$-axis (FL-3). Unstained cells were detected near the origin with respect to the $X$-axis. Data were analysed using Flomax software (Vs 2.0, 1999, Partec GmbH, Münster, Germany). The FL-3 fluorescence data were displayed as one-dimensional histograms for determination of proportion of cells responding to the treatment. Ranges were delineated to discriminate between membrane-intact and membranedefective spermatozoa.

\section{Data analysis}

The results presented are based on the means from three and six independent experiments. Observed effects were verified by ANOVA, $t$-test and non-parametrical analysis (SAS Software, SAS Institute Inc., Cary, NC, USA). Unless stated otherwise, the values presented are mean \pm s.E.M. Differences were considered to be significant if the calculated probability of their occurring by chance was $<5 \%(P<0.05)$.

\section{Results}

\section{Protein kinase-dependent pathways}

Four inhibitors of protein kinases were probed in this experimental series in the ranges indicated in Table 1: staurosporine (potent general inhibitor of protein kinases with very high potency for PKC, though PTK also inhibited and, to a much lesser extent, PKA), Bis I (PKC inhibitor with less potency for PKA), lavendustin A (inhibitor of PTK) and H-89 (PKA inhibitor).

The addition of protein kinase inhibitors to incubation and testing media resulted in a concentration-dependent increase $(P<0.01)$ in the isotonic sperm volume (Fig. 1 and Table 2). Even at $1 \mu \mathrm{mol} / \mathrm{l}$ concentration,

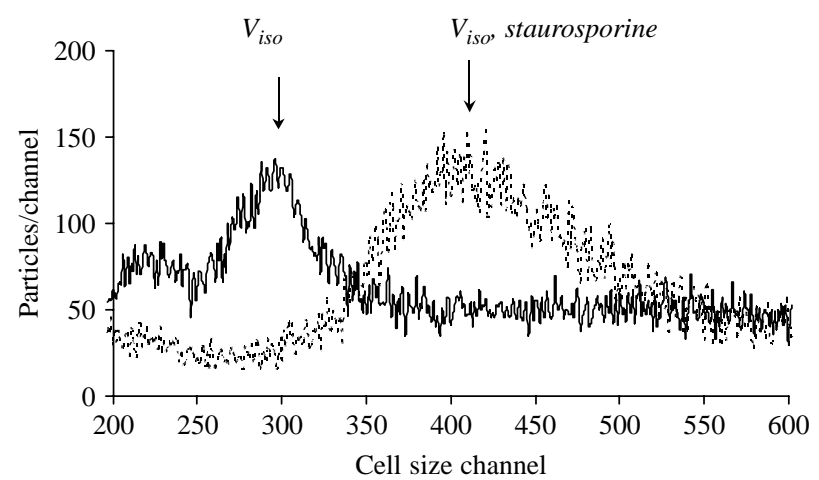

Figure 1 Effect of staurosporine, a protein kinase inhibitor, on sperm cell volume in isotonic medium. Solid line indicates control (no inhibitor) sperm volume distribution; broken line indicates volume distribution in the presence of $5 \mu \mathrm{mol} / \mathrm{l}$ staurosporine. Note that the isotonic volume distribution curve is shifted to the right by the protein kinase inhibitor; in other words, the cell volume of the majority of cells in the population is increased. staurosporine, Bis I and lavendustin A caused 40-50\% increases in isotonic volume when compared with control values $(P<0.05)$, whereas a comparable effect of the PKA inhibitor $\mathrm{H} 89$ was observed only at a concentration of $15 \mu \mathrm{mol} / \mathrm{l}$.

Similarly, incubation with the protein kinase inhibitors resulted in a concentration-dependent increase $(P<0.05)$ in hypotonic cell volume (Table 2 , and compare Fig. 2a and b). However, the increase in volume caused by exposure to hypotonic conditions in the presence of staurosporine, lavendustin $\mathrm{A}$ or $\mathrm{H}-89$ was similar to the increase in isotonic volume (e.g. Fig. 2a and b). Thus, the relative volume shift after 5 and 20 min was generally comparable to or lower than that in the control, indicating the maintenance of volume regulatory response (Fig. 3). Nevertheless, in our experiments, due to considerable variation between samples, the tendency of acceleration of volume regulatory response was not statistically significant. Treatment with the PKC inhibitor Bis I, on the other hand, resulted in both higher initial swelling and a very strong degree of RVD; after $20 \mathrm{~min}$ of exposure to hypotonic medium in the presence of $5 \mu \mathrm{M}$ Bis I, the relative volume shift was lower $\left(V_{\mathrm{r}}=1.06\right)$ than in the control $\left(V_{\mathrm{r}}=1.32 ; P<0.06\right)$ and the regulatory volume change $\left(\Delta V_{\mathrm{r}}=V_{\mathrm{r}, 20}-V_{\mathrm{r}, 5}\right)$ was significantly higher than in the control $(-0.88$ in Bis I-treated samples vs -0.38 in control; $P<0.05$ )

Unfortunately, the treatment of sperm with Bis I led to considerable increases in cell death (at a concentration of $5 \mu \mathrm{mol} / \mathrm{l}, 60-70 \%$ of sperm became Pl-positive), whereas incubation with the other inhibitors even at the highest concentrations tested did not significantly affect the membrane integrity (PI-positive cells: $11-17 \%$ in staurosporine, $12-24 \%$ in lavendustin, $14-23 \%$ in $\mathrm{H} 89$ as against $10-15 \%$ in controls). It should be pointed out that this effect of Bis I did not invalidate our conclusions because we were observing swelling effects, and any swelling observed was necessarily due to the response of membrane intact, i.e. live, cells. However, because of this toxic effect of Bis I, we sought another PKC inhibitor, which was less detrimental. Bisindolylmaleimide X (Bis X), which specifically inhibits PKC with an $\mathrm{IC}_{50}$ similar to Bis I, and bisindolylmaleimide $\mathrm{V}$ (Bis V), a negative control, had no

Table 2 Effect of protein kinase inhibitors on isotonic and hypotonic volumes.

\begin{tabular}{lccc}
\hline Inhibitors & $\begin{array}{c}\text { Concentration } \\
(\mu \mathrm{mol} / \mathrm{l})\end{array}$ & $\boldsymbol{V}_{\text {iso, }} \mathbf{2 0} \mathbf{~ m i n}(\mathrm{fl})$ & $\boldsymbol{V}_{\text {hypo, }} \mathbf{2 0} \mathbf{~ m i n}(\mathrm{fl})$ \\
\hline Control & - & $15.7 \pm 0.4$ & $20.8 \pm 1.2$ \\
Staurosporine & 0.1 & $18.2 \pm 1.4$ & $27.6 \pm 4.8$ \\
& 1 & $22.3 \pm 2.6$ & $30.4 \pm 4.8$ \\
Bis I & 1 & $21.4 \pm 3.1$ & $25.3 \pm 2.3$ \\
& 5 & $31.9 \pm 2.4$ & $32.8 \pm 1.7$ \\
Lavendustin A & 1 & $21.2 \pm 2.8$ & $29.5 \pm 4.2$ \\
& 5 & $30.1 \pm 1.47$ & $36.0 \pm 4.8$ \\
H 89 & 5 & $18.5 \pm 1.7$ & $24.5 \pm 2.9$ \\
& 15 & $21.6 \pm 2.4$ & $34.0 \pm 3.4$ \\
\hline
\end{tabular}



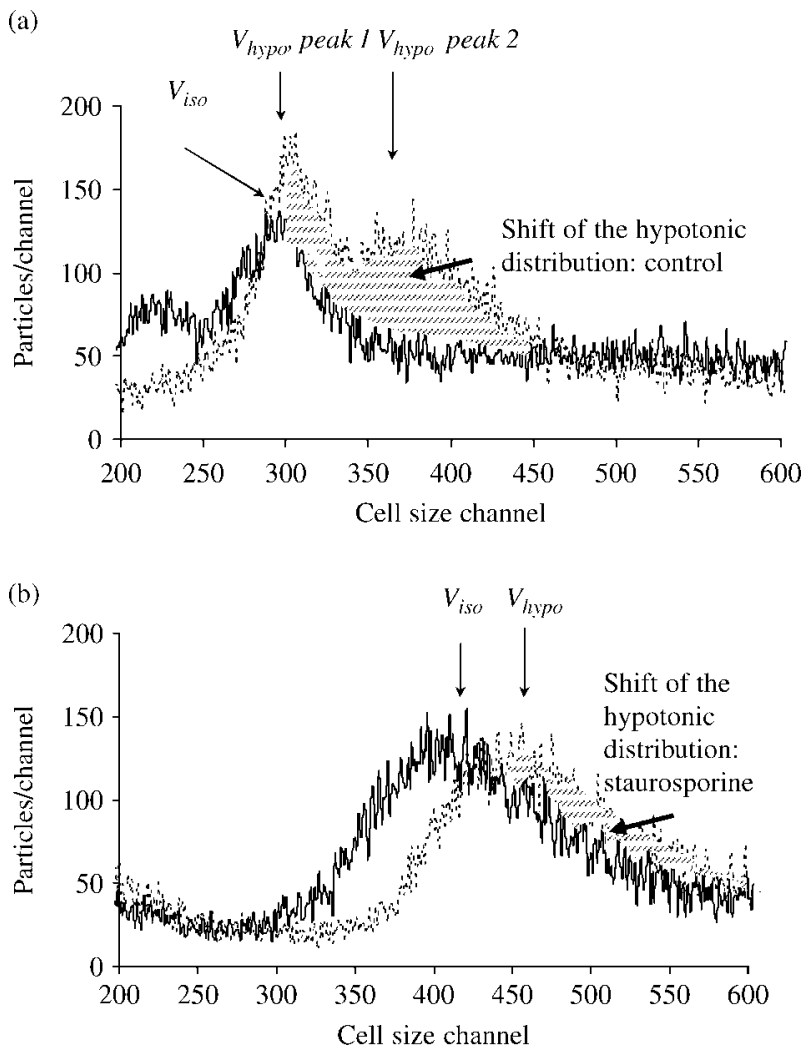

Figure 2 Effect of the protein kinase inhibitor staurosporine on osmotically induced cell volume regulation in spermatozoa. (a) Volume shift in control media (no kinase inhibitor). Solid line indicates sperm volume distribution in isotonic medium; broken line indicates volume distribution in hypotonic medium. The volume distribution is shifted to the right side in hypotonic medium as compared with the distribution in isotonic medium, demonstrating swelling of the cells in response to hypotonic conditions. (b) Volume shift in the presence of $5 \mu \mathrm{mol} / \mathrm{l}$ staurosporine. Solid line indicates volume distribution in isotonic medium, broken line indicates volume distribution in hypotonic medium. Both distributions are shifted to the right as compared with the control distributions in (a). However, the relative degree of swelling resulting from hypotonic stress (shaded area) was less in the presence of staurosporine than it was in the control. This demonstrates an enhancement of RVD.

significant effect on cell death in concentrations between 0.3 and $1 \mu \mathrm{mol} / \mathrm{l}$ (PI-positive cells: $12-26 \%$ in Bis X, $9-21 \%$ in Bis $\mathrm{V}, 8-23 \%$ in controls).

As expected, after addition of Bis $\mathrm{X}$ to the incubation suspensions the isotonic sperm volume increased in a dose-dependent fashion. However, at $1 \mu \mathrm{mol} / \mathrm{l}$ the effect of Bis X was not as dramatic as that of Bis I - the former induced a volume increase of about $21 \%$ as compared with the control (no inhibitor) volume, whereas the latter induced an increase of about $36 \%$. There were no changes in isotonic cell volume in samples treated with Bis V, but after $20 \mathrm{~min}$ of exposure to hypotonic conditions, the hypotonic cell volume (and $V_{r}$ ) still remained high, whereas $V_{r}$ was decreased in Bis X-treated cell suspensions (Fig. 4a). Although the inactive analogue, Bis $\mathrm{V}$, appeared to produce an

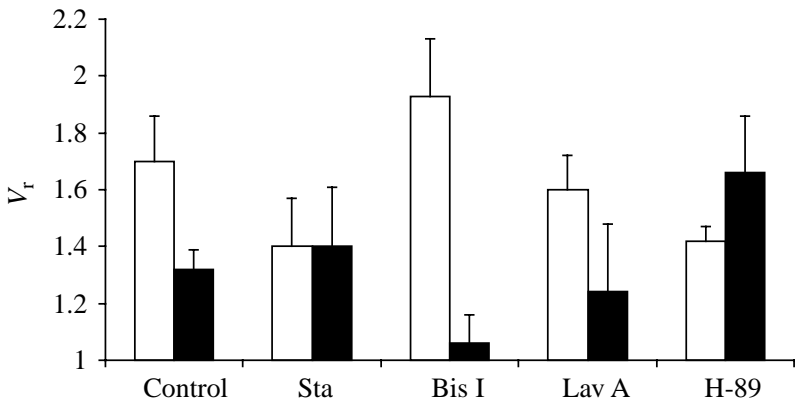

Figure 3 Effect of protein kinase inhibitors on sperm cell volume regulation. Data are presented as $V_{\mathrm{r}}\left(=V_{\text {hypo }} / V_{\text {iso }}\right)$. Open bars are $V_{\mathrm{r}, 5}$, closed bars are $V_{r, 20}$. Control, no inhibitor present; Sta, $1 \mu \mathrm{mol} / \mathrm{l}$ staurosporine; Bis I, $5 \mu \mathrm{mol} / /$ bisindolylmaleimide I; Lav A, $5 \mu \mathrm{mol} / \mathrm{I}$ lavendustin $\mathrm{A} ; \mathrm{H}-89,15 \mu \mathrm{mol} / \mathrm{l} \mathrm{H}-89$. Note that because of sample variation, only the changes brought about by Bis I were statistically significant $(P<0.05)$.

(a)

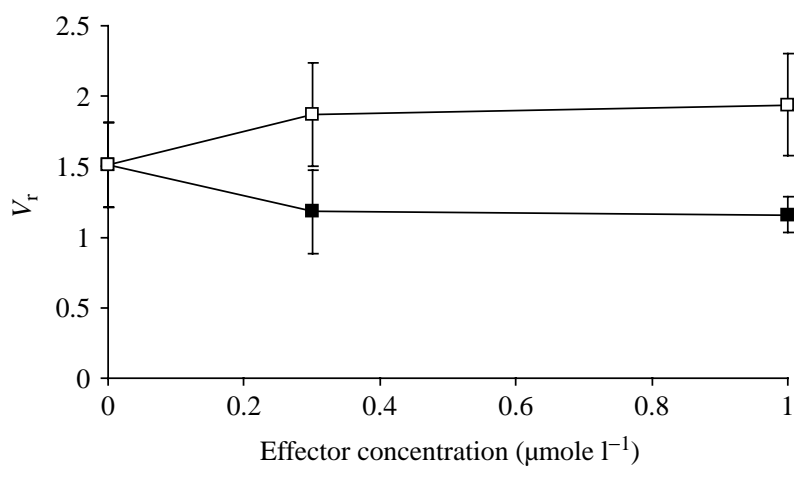

(b)

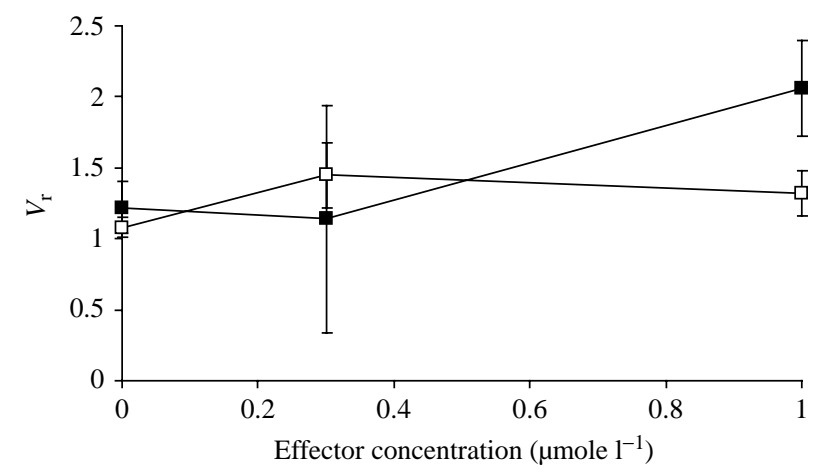

Figure 4 Effect of protein kinase $C$ effectors on sperm cell volume regulation. (a) Effects of bisindolylmaleimides $X$ and $V$. Bis $X$ (solid symbols), a specific inhibitor of protein kinase $C$, led to lowered relative volume shift after $20 \mathrm{~min}$ of incubation under hypotonic conditions as compared with control (no effector present), i.e. it enhanced volume recovery after initial swelling. In the presence of Bis $V$ (open symbols), an inactive analogue of Bis X, swelling levels after 20 min remained high or even increased. (b) Effects of phorbol esters on volume regulation. Solid symbols, PDBu; open symbols, $\alpha$-PDBu. While elevated swelling levels were observed in response to $1 \mu \mathrm{mol} / / \mathrm{PDBu}$, an activator of PKC, the relative volume was considerably lower in the presence of a similar concentration of its inactive analogue, $\alpha$-PDBu. 
elevation in the hypotonic cell volume when compared with the control hypotonic volume, a markedly significant difference was observed between the effects of the active and inactive analogues; at all concentrations tested, the relative volume shift was higher in the cell suspensions incubated with $B$ is $V$ than in those incubated with Bis $X(P<0.05$, Fig. 4a).

The results above suggested strongly that PKC played an important role in volume control. To confirm this, we investigated the effect of PKC activation with the phorbol dibutyrate $\mathrm{PDBu}$ at concentrations between 0.3 and $3 \mu \mathrm{mol} / \mathrm{l}$, as the levels of membrane-defective sperm were found not to be significantly increased at these concentrations. The isotonic volume was not affected either by PDBu or by $\alpha$-PDBu (an inactive phorbol ester), although the latter led to values nominally larger than those of the controls (not significant; $P>0.05$ ). After 5 min exposure to hypotonic conditions, there was no difference in $V_{\mathrm{r}}$ between samples treated with either PDBu or $\alpha$-PDBu (data not shown), but $V_{r}$ was increased by PDBu in a dosedependent fashion after 20 min exposure (Fig. 4b). After $20 \mathrm{~min}$ in the presence of $3 \mu \mathrm{mol} / \mathrm{I} \mathrm{PDBu}$, the hypotonic volume increased to $20.8 \mathrm{fl}$ as compared with $11.8 \mathrm{fl}$ in control suspensions $(P<0.01)$. At $0.3 \mu \mathrm{mol} / \mathrm{I} \mathrm{PDBu}$, no significant effects were observed due to big sample variations but RVD was inhibited at $1 \mu \mathrm{mol} / \mathrm{l}$ concentration of PDBu; the swelling progressed over $20 \mathrm{~min}$ $\left(\Delta V_{\mathrm{r}}=0.67\right)$, whereas it showed a recovery $\left(\Delta V_{\mathrm{r}}=-0.45\right)$ in control suspensions $(P=0.054)$ and was maintained in place in $\alpha$-PDBu-treated suspensions $\left(\Delta V_{\mathrm{r}}=0.00\right)$. Furthermore, the volume set point (i.e. $V_{r, 20}$ ) was 1.88 in PDBu-treated suspensions (at $3 \mu \mathrm{M})$, whereas it was 1.22 in the control $(P<0.05)$.

To see if PKC was acting to control chloride fluxes, the effects of Bis $X$ were tested in isotonic medium in which chloride was replaced by sulfate (isoSulf). In isoSulf, the increase in $V_{\text {iso }}$ induced by Bis X in HBS was abolished and replaced by a slight volume decrease. Whereas $3 \mu \mathrm{mol} / \mathrm{l}$ Bis $X$ produced a $V_{\text {iso,20 }}$ of $19.9 \pm 1.9 \mathrm{fl}$ in HBS, in isoSulf it produced a $V_{\text {iso,20 }}$ of $11.6 \pm 1.0 \mathrm{fl}(P<0.05$ for difference). These $V_{\text {iso,20 }}$ values compared with control values of $12.6 \pm 0.6 \mathrm{fl}$ in HBS.

These results suggested strongly that the increased isotonic volume caused by inhibition of PKC is due to the opening of chloride channels, and that PKC acts to maintain these channels in an inactive state. The increased $V_{\mathrm{r}}$ resulting from PKC activation would seem to be due to the defective opening of the channels and thus the inability of $\mathrm{Cl}^{-}$to exit with $\mathrm{K}^{+}$to maintain tonicity across the cell plasma membrane.

\section{Protein phosphatase-dependent pathways}

Given the effect of protein kinase inhibitors, it seemed logical to investigate the involvement of the dephosphorylation processes in sperm volume control. Two inhibitors of protein phosphatase PP1 and PP2A, okadaic acid and calyculin, were tested at concentrations of 10 and $100 \mathrm{nmol} / \mathrm{l}$ (see Table 1). Although both inhibitors led to increased isotonic volumes, the effects (Table 3) were not nearly as large as those of the protein kinase inhibitors (3-4 vs 10-20 fl) and occurred only after longer incubation.

At a dosage of $10 \mathrm{nmol} / \mathrm{l}$, both inhibitors led to increased hypotonic volumes, which varied between 43.7 and $49.2 \mathrm{fl}$ as compared with a control hypotonic volume of $25.4 \mathrm{fl}(P<0.05$; see Table 3$)$. Whereas protein kinase inhibitors had similar marked effects on both isotonic and hypotonic volumes, the protein phosphatase inhibitors had a much more pronounced effect on hypotonic than on isotonic volume (compare Fig. $5 \mathrm{~b}$ with a). At $10 \mathrm{nmol} / \mathrm{l}$ okadaic acid or calyculin, at which no effect on isotonic cell volume was observed, RVD was blocked (Fig. 6). The relative volume change $\Delta V_{\mathrm{r}}$ showed an increase in treated samples $(+0.3$ and +0.50 for okadaic acid and calyculin respectively), whereas in control samples, it showed a decrease $(-0.64)$.

Treatment with ortho-vanadate, an inhibitor of TP, led to somewhat increased isotonic volumes, but this tendency was not significant. There was also a tendency towards reduction of $V_{\mathrm{r}}$ after $5 \mathrm{~min}$, and after $20 \mathrm{~min}$ RVD was blocked significantly $(P<0.05)$. There was a progressive increase in the cell volume $\left(\Delta V_{\mathrm{r}}=+0.21\right)$, whereas in the control the normal markedly progressive decrease in cell volume was observed $\left(\Delta V_{\mathrm{r}}=-0.52 ; P<0.05\right)$.

\section{cAMP-dependent pathways}

Cyclic AMP effects are widely mediated via its activation of PKA. Yet, during the experiments with protein kinase inhibitors, it was noticeable that inhibition of PKA with $\mathrm{H}-89$ did not have a great effect on isotonic volume (Table 2) although it did tend to reduce hypotonic swelling (non-significantly; Fig. 3). While PKA is the best-known target of cAMP, the second messenger can act by other means. There are various ways to elevate

Table 3 Effects of protein phosphatase and phosphodiesterase inhibitors on isotonic and hypotonic cell volumes.

\begin{tabular}{lccccc}
\hline & Control & OA & Cal & OA + Pap & Cal+Pap \\
\hline$V_{\text {iso, }} 20 \mathrm{~min}$ & $15.1 \pm 0.6$ & $17.5 \pm 2.4$ & $17.6 \pm 1.4$ & $21.2 \pm 4.1$ & $21.4 \pm 1.1^{*}$ \\
$V_{\text {hypo }} 20 \mathrm{~min}$ & $25.4 \pm 2.5$ & $43.7 \pm 2.9^{*}$ & $49.2 \pm 1.2^{*}$ & $34.1 \pm 0.7^{*}$ & $19.3 \pm 1.0^{*}$ \\
\hline
\end{tabular}

OA, $10 \mathrm{nM}$ okadaic acid; Cal, $10 \mathrm{nM}$ calyculin; Pap, $20 \mu \mathrm{M}$ papaverine. *Values labelled with asterisks differ significantly from the controls within the same row $(P<0.05)$. Effect of papaverine alone $(20 \mu \mathrm{M})$ were tested against split-sample controls in a seperate experiment. 

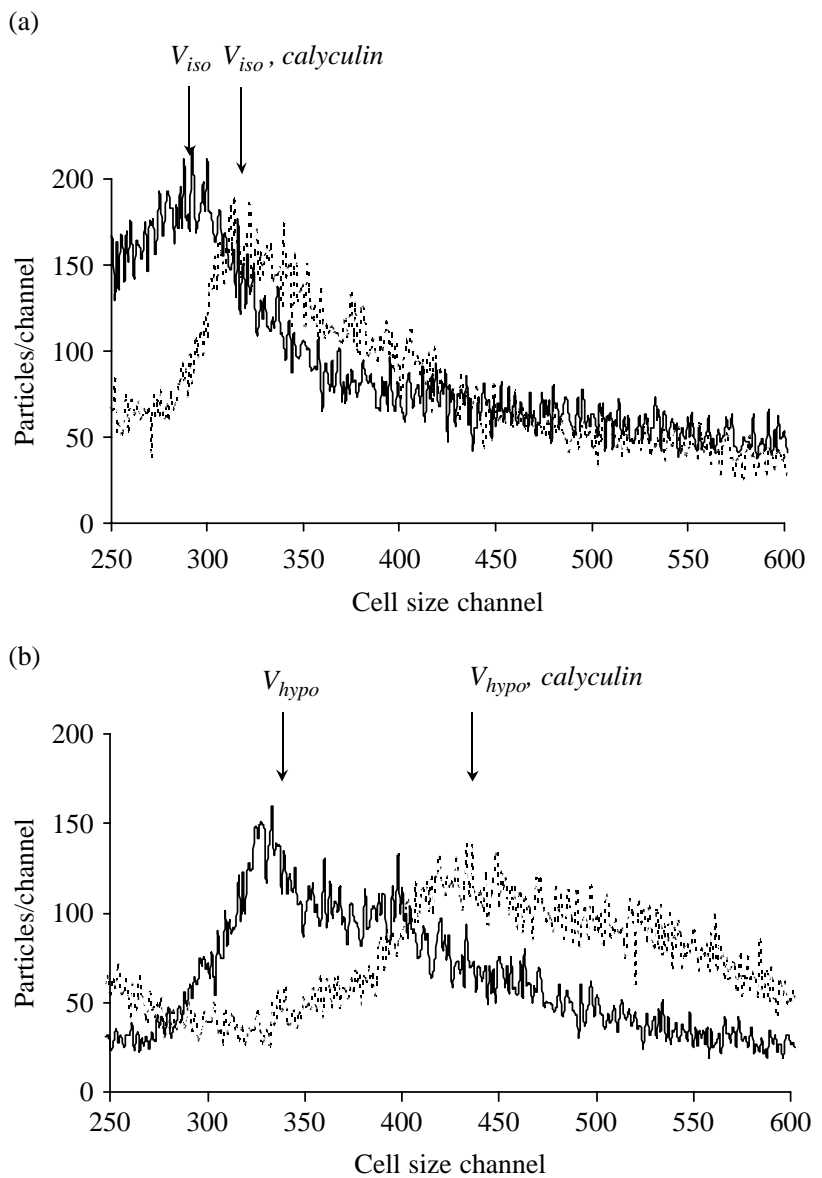

Figure 5 The effects of calyculin, a PP1 protein phosphatase inhibitor, on sperm cell volume. (a) Effect on the isotonic volume distribution curve $(20 \mathrm{~min}$ exposure, $100 \mathrm{nmol} / \mathrm{l}$ calyculin, $300 \mathrm{mosmol} / \mathrm{kg}$ ). Solid line indicates control (no inhibitor) curve; broken line indicates calyculin curve. (b) Effect on the hypotonic volume distribution curve ( $20 \mathrm{~min}$ exposure, $100 \mathrm{nmol} / \mathrm{l}$ calyculin, $180 \mathrm{mosmol} / \mathrm{kg}$ ). The degree of shift of the curve produced by calyculin is much greater under hypotonic conditions, i.e. RVD is blocked.

cAMP levels: for example, direct stimulation of adenylate cyclase activation by forskolin (Leclerc \& Kopf 1995) or inhibition of cAMP phosphodiesterase by papaverine (reported particularly for boar sperm, Harrison \& Miller 2000). Both methods were used here.

Forskolin (FSK) and its biologically inactive analogue dideoxyforskolin (DDFSK) were tested at concentrations between 1 and $10 \mu \mathrm{mol} / \mathrm{l}$. Under isotonic conditions, both FSK and DDFSK caused significant increases in cell volumes $(P<0.05)$. Whereas FSK at a concentration of only $5 \mu \mathrm{mol} / \mathrm{l}$ caused a significant increase in $V_{\text {iso }}$ after 5 min, only treatment with the highest concentration of DDFSK $(10 \mu \mathrm{M})$ resulted in volumes significantly different from those of the controls. A similar increased sensitivity to FSK as compared with DDFSK was also observable after 20 min (Fig. 7a).

At the lowest concentration tested $(1 \mu \mathrm{mol} / \mathrm{l})$, both FSK and DDFSK had similar effects on the hypotonic

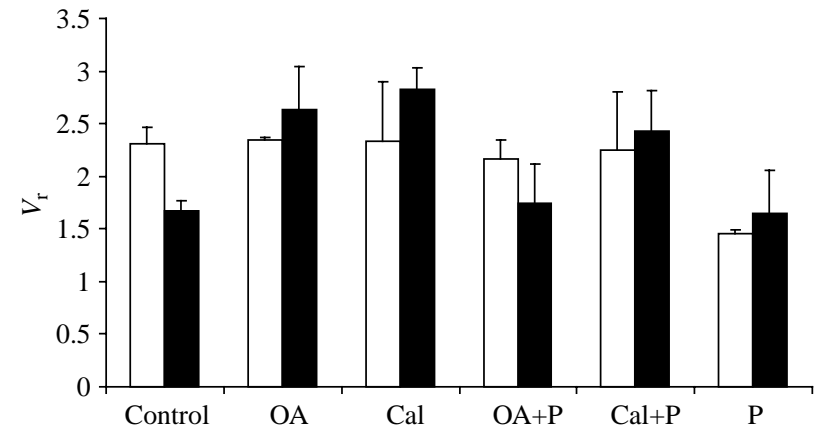

Figure 6 Effect of protein phosphatase inhibitors and papaverine on sperm cell volume regulation. OA, $10 \mathrm{nmol} / \mathrm{l}$ okadaic acid; Cal, $10 \mathrm{nmol} / \mathrm{I}$ calyculin; Pap, $20 \mu \mathrm{mol} / \mathrm{l}$ papaverine. Open bars are $V_{\mathrm{r}, 5}$; closed bars are $V_{r, 20}$. Inhibiting protein phosphatase blocked the RVD process. However, Pap accelerated RVD (lower $V_{r, 5}$ than control) and inclusion of Pap with OA overcame the latter's blocking of RVD (the effect of Pap with Cal was much less clear). This effect of Pap indicates an involvement of cAMP in the RVD process. Effects of papaverine alone $(20 \mu \mathrm{M})$ were tested against split-sample controls in a seperate experiment.

volume, RVD was inhibited. The relative volume shift remained at a stable high level (between 2.19 and 2.12) during 20 min incubation with FSK under hypotonic conditions, and even increased significantly during incubation with DDFSK $\left(V_{\mathrm{r}, 5}=2.32 ; V_{\mathrm{r}, 20}=2.95\right)$, while RVD was observed in the control $\left(V_{\mathrm{r}, 5}=2.32\right.$; $\left.V_{\mathrm{r}, 20}=1.90 ; P<0.05\right)$. Above this concentration, incubation with FSK caused a decrease in $V_{r}$ after 5 and 20 min of exposure (i.e. RVD was enhanced; Fig. 7b). Although inhibition of RVD was also reversed at higher concentrations of DDFSK, this occurred more slowly, i.e. after $20 \mathrm{~min}$ and not after $5 \mathrm{~min}$ incubation; thus the effect of FSK was faster than that of DDFSK. At $10 \mu \mathrm{mol} /$ $\mathrm{I}$, there was a significant difference between forskolin and its inactive analogue in their effect on relative sperm volume after $5 \mathrm{~min} \quad\left(V_{\mathrm{r}, 5}=1.48\right.$ and $V_{\mathrm{r}, 5}=2.11$ respectively).

At a concentration of $20 \mu \mathrm{mol} / \mathrm{l}$, the inhibitor of cAMP phosphodiesterase, papaverine, caused a significant increase in isotonic volume both after $5 \mathrm{~min}(17.9 \mathrm{fl}$; control, $14.5 \mathrm{fl}$ ) and after $20 \mathrm{~min}(19.3 \mathrm{fl}$; control, $15.1 \mathrm{fl}$, Table 3); it also caused a marked acceleration of RVD, $V_{\mathrm{r}, 5}=1.46$ as compared with the control, $V_{\mathrm{r}, 5}=1.93$ $(P<0.05)$. The addition of papaverine to the samples incubated with okadaic acid and calyculin induced isotonic swelling when the phosphatase inhibitors alone had no effect (Table 3). Moreover, papaverine reversed the increased hypotonic volume and relative swelling induced by the phosphatase inhibitors (Table 3; Fig. 6). Although resulting cell volumes were much greater than in the control suspensions $(P<0.05)$, and usually greater than with phosphodiesterase inhibitor alone, the relative volume shifts were diminished after $5 \mathrm{~min}$ and especially after 20 min (Fig. 6). Although cell death increased significantly during treatment with $100 \mathrm{nmol} / \mathrm{l}$ concentrations of the phosphatase inhibitors, the proportion of 
(a)

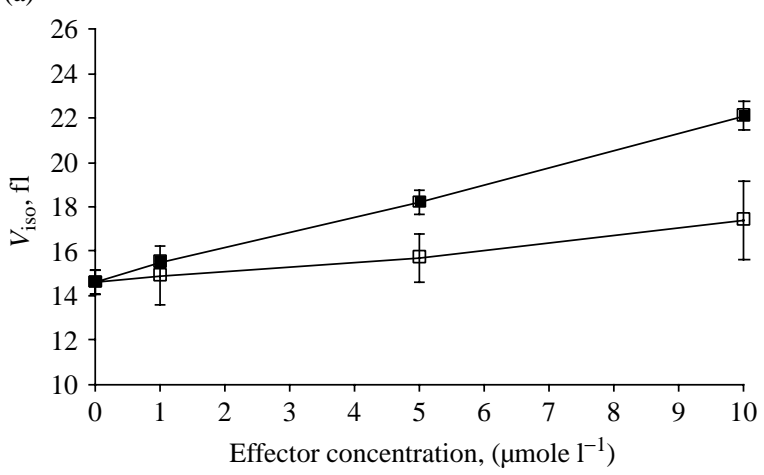

(b)

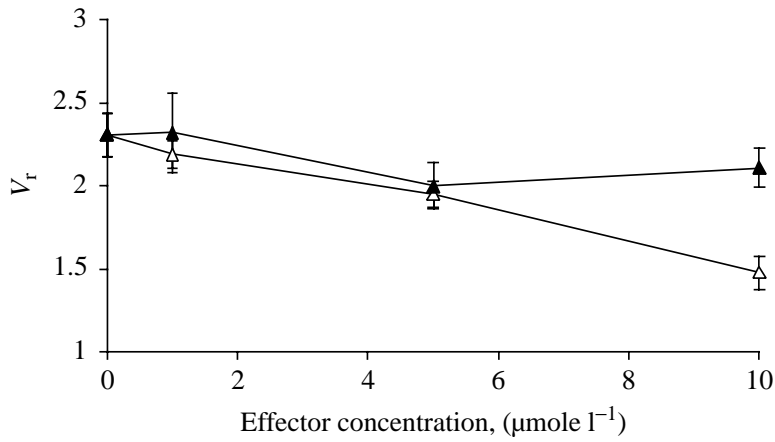

Figure 7 Effect of forskolin on sperm cell volume. (a) Effects of FSK (forskolin, solid symbols) and DDFSK (inactive di-deoxy-forskolin, open symbols) on isotonic cell volume after 20 min of incubation. Both drugs led to increased isotonic cell volume, although FSK was significantly more potent at concentrations of 5 and $10 \mu \mathrm{mol} / \mathrm{l}$. (b) Effects of FSK (open symbols) and DDFSK (solid symbols) on the relative volume shift after 5 min incubation under hypotonic conditions. At a concentration of $10 \mu \mathrm{mol} / \mathrm{l}$, treatment with FSK resulted in lower swelling levels than did its inactive analogue (thus accelerated volume regulation).

propidium iodide-positive cells remained between 25 and $30 \%$, even after the addition of papaverine (control: $15 \%)$, so that most cells in the population may be considered to have been intact. At $10 \mathrm{nmol} / \mathrm{l}$, no effect of calyculin and okadaic acid on membrane integrity was seen. Thus, the effects detected could be clearly attributed to changes in the live cell population.

As a general note regarding the results described above, percipient readers may wonder whether the presence of subpopulations of spermatozoa bearing attached cytoplasmic droplets might have distorted our findings. Although the additional cellular volume due to attached and/or free cytoplasmic droplets is detectable within population distributions obtained from electronic sizing $\left(9-11 \mu \mathrm{m}^{3}\right.$ at $20^{\circ} \mathrm{C}$; O'Donnell 1969, Brotherton 1975), effectors were tested with respect to changes induced in modal volumes, not means or medians, so that the contribution of minor populations of droplets (attached or free) to the osmotic response would not have affected materially the overall response of the main sperm populations.

\section{Discussion}

The findings from the experiments described above have been able to link mechanisms for maintaining sperm cell volume under isotonic conditions with those leading to RVD after exposure of the sperm cell to hypotonic conditions. RVD involves swelling-sensitive opening of $\mathrm{K}^{+}$and $\mathrm{Cl}^{-}$channels to allow exit of ions so as to maintain osmotic equilibrium, whereas maintenance of cell volume under isotonic conditions requires that these channels be maintained in an inactive (closed) state. Premature activation of the channels under isotonic conditions results in the entry of $\mathrm{Cl}^{-}$and $\mathrm{Na}^{+}$down concentration gradients, whence increased osmotic pressure and resultant swelling to re-establish osmotic equilibrium. Our results have shown for the first time that PKC is involved in maintaining sperm isotonic volume by suppressing ion transport, whereas cyclic AMP is involved in stimulating sperm RVD by activating ion transport. Activation of sperm ion transport and RVD also involves the serine/threonine phosphatase PP1. A schematic representation of our findings is shown in Fig. 8.

PKC inhibitors led to sperm swelling in both isotonic and hypotonic media (Figs 1 and $2 \mathrm{a}$ and b). That inhibitor-induced isotonic swelling did not take place in a medium in which $\mathrm{Cl}^{-}$had been replaced with sulfate suggests that PKC acts largely on chloride ion channels. We have recently shown that certain inhibitors of chloride channels (e.g. tamoxifen) lead to increased isotonic volume, whereas others (e.g. NPPB(5-nitro-2-(3phenylpropylamino)-benzoic acid)) affect only hypotonic volume (Petrunkina et al. 2004a). An alternative explanation for the effect of kinase inhibitors on isotonic volume in spermatozoa might have been that they caused enhancement of taurine flux (e.g. in glial cells; Deleuze et al. 2000); however, it has recently been shown that taurine efflux is not essentially involved in volume control in boar or human spermatozoa, although it does play a role in mouse sperm RVD (Yeung et al. 2003, 2004, Petrunkina et al. 2004a). While staurosporine, lavendustin and Bis I led to comparable increases in isotonic volume, the effect of the PKC inhibitor Bis $X$ was less. This suggests that the maintenance of transport mechanisms in an inactive state involves both PTK- and PKC-dependent pathways. It has recently been shown that tyrosine phosphorylation is involved in the sequence leading to the deactivation of sperm volume regulatory mechanisms (Petrunkina et al. 2005b), whereas in somatic cells ion channels are opened by tyrosine kinase (Lepple-Wienhues et al. 2000). Moreover, some ion channels in human-derived renal epithelial cell line HEK 293 cells, such as the voltage-gated potassium channel of the KCNQ4 family, have been reported to be inactivated via protein kinase $\mathrm{C}$ activity under isotonic conditions (Hougaard et al. 2004). 
(a)

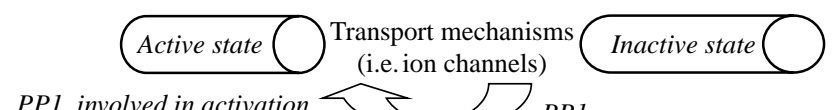

PPI involved in activation $>P P 1$

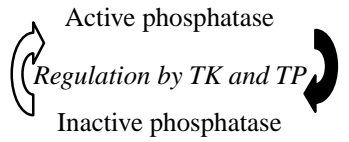

(b)

Elevated cAMP levels lead to activation cAMP

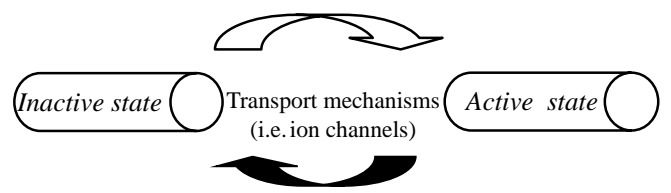

Phosphodiesterase lowers cAMP levels and reduces activation

Figure 8 Osmo-signalling pathways in spermatozoa. (a) PKC/PP1dependent pathway controlling maintenance of cell volume. PKC is involved in the signalling sequence that leads to deactivation of the osmo-dependent regulatory mechanism, probably by closing and keeping closed a volume-sensitive anion channel. Inhibition of PKC results in premature activation of the channel, increased isotonic cell volume and prolonged and/or accelerated volume regulation. Protein phosphatase PP1 is involved in the signalling sequence that leads to the activation of the volume regulatory mechanism, probably by opening the volume-sensitive ion channels (by dephosphorylation of the residues phosphorylated by PKC?). Thus, inhibition of protein phosphatase PP1 results in blocked RVD. A PTK/TP-dependent system may regulate PP1 activity (transition between active and inactive forms). (b) cAMP-dependent pathway activating regulatory volume decrease. Activation of the volume regulatory mechanism appears to be cAMP-sensitive. An increase in intracellular cAMP is associated with activation of volume regulatory mechanisms usually inactive under isotonic conditions: activation of adenylate cyclase by forskolin leads to increased isotonic cell volume and to accelerated swelling recovery in response to hypotonic conditions. Inhibition of phosphodiesterase results in increased cAMP levels and similar effects. Notably, increased cAMP levels can overcome inhibition of the PP1-dependent pathway. Evidence for the involvement of PKA in the cAMP-dependent pathway was equivocal.

Hypotonic conditions can lead to the activation of protein kinase C (Lang et al. 1998). Larsen et al. (1994) reported that this activation occurs during late stages of RVD. The fact that the PKC inhibitor Bis I enhanced the amplitude of sperm RVD and resulted in a lowering of the volume set point, i.e. the resultant volume following RVD (see Fig. 3), agrees with their findings and suggests that PKC may be responsible for the termination of RVD, i.e. by closing an ion channel (see Fig. 8). (Note that the internal accumulation of $\mathrm{Cl}^{-}$and $\mathrm{Na}^{+}$ions during isotonic swelling caused by the opening of channels (see above and Fig. 1) will tend to amplify the RVD process because the lower $\mathrm{NaCl}$ concentration in the external hypotonic medium will initially induce water influx into the cells. Moreover, if the isotonic swelling during drug pretreatment was not due to the premature opening of ion channels, no relative shrinking during hypotonic exposure would take place; rather, a further progressive swelling would be observed under hypotonic conditions.) Our findings mirror those of Hoffmann (2000) who reported that another PKC inhibitor, chelerythrine, decreased the volume set point in Ehrlich ascites tumour cells after RVD. Further evidence that PKC acts to close ion channels is provided by our demonstration that the PKC activator phorbol dibutyrate causes elevated levels of relative swelling in response to hypotonic conditions (Fig. 4b).

Although PTK-dependent pathways appear to be involved in sperm volume regulation under both isotonic and hypertonic conditions (Petrunkina et al. 2005b), tyrosine phosphorylation seems to play a less crucial role in sperm exposed to hypotonic conditions (see effects of lavendustin and vanadate).

Under hypotonic conditions, protein serine/threonine phosphatase inhibitors had a marked effect on RVD. Both calyculin A and okadaic acid inhibited RVD at low concentrations $(10 \mathrm{nmol} / \mathrm{l})$. It has been suggested that swelling in response to hypotonic conditions inhibits a kinase, favouring dephosphorylation and leading to transport mechanism activation (Dunham et al. 1993, Bize \& Dunham 1994). Okadaic acid has been shown to block activation of the volume-sensitive chloride current in a non-pigmented ciliary epithelial cell line (Shi et al. 2002), indicating that dephosphorylation is involved in the opening of chloride channels in this cell type. In our experiments, calyculin was more efficient than okadaic acid in inhibiting RVD: at $10 \mathrm{nmol} / \mathrm{l}$, its inhibitory effect was barely affected by papaverine, whereas the inhibitory effect of $10 \mathrm{nmol} / \mathrm{l}$ okadaic acid was largely reversed by papaverine (see Table 3 and Fig. 6). Thus, as both inhibitors have approximately the same potency against PP2A, and calyculin has a higher potency against PP1, we conclude that it is PP1 that is involved in the signalling sequence leading to channel opening in sperm (Fig. 8).

Our findings indicate that CAMP plays a major role in ion channel activation. At low concentrations, forskolin, a potent stimulator of adenylate cyclase, increased isotonic volumes (Fig. 7a) and enhanced RVD (Fig. 7b). The phosphodiesterase inhibitor papaverine, at a concentration sufficient to elevate cAMP levels in boar sperm (Harrison \& Miller 2000), also led to a significant increase in both isotonic volume and RVD. As the cAMP effectors had an accelerating effect on RVD as well as an enhancing one, it is likely that cAMP is involved in the signalling pathway, which leads to the opening of the channel (Fig. 8). This hypothesis is supported by the fact that papaverine was able to reverse the inhibition of RVD by okadaic acid at $10 \mathrm{nmol} / \mathrm{l}$ (Fig. 6). Our finding is interesting because, although cAMP has been reported to decrease the volume of a wide variety of cells 
(MacLeod et al. 1994, Lang et al. 1998), it has also been reported that $\mathrm{Cl}^{-}$conductance operated by cAMP and PKA is activated by the addition of forskolin in some cell types, such as rat cardiomyocytes and dog ciliary epithelium (Chen et al. 1994, Tilly et al. 1996). What is intriguing about our results is that the cAMP pathway that activates ion channels in sperm does not appear to involve PKA to any major extent: at $5 \mu \mathrm{mol} / \mathrm{l}$ the PKA inhibitor $\mathrm{H}-89$ had little effect on isotonic volume, whereas similar concentrations of Bis I and lavendustin increased it markedly (Table 2). Moreover, in contrast to the cAMP effectors, $\mathrm{H}-89$ produced no significant effects on $V_{r}$ after $20 \mathrm{~min}$ (Fig. 3). This finding suggests that cAMP may act directly to gate the ion channels (cf. Galindo et al. 2005).

It remains unclear as to whether the various kinases, phosphatases and cAMP identified as being involved in volume regulation act on the same target protein or whether they act on different targets under different conditions, determined by osmolality or cell volume. Hougaard et al. (2004), for example, reported that isotonic volume was affected by PKC, PKA and $\mathrm{Ca}^{2+}$, but that these mechanisms were not responsible for increased activity during cell swelling. However, because isotonic sperm swelling induced by PKC inhibition was abolished in a medium containing sulfate instead of chloride, it appears more likely that PKC is involved in the closing of chloride channels both under isotonic and hypotonic conditions. In this case, the same target is addressed, but the cellular response is determined by internal and external ionic concentrations; this may account for the wide variability of individual response reported in our recent studies (Petrunkina et al. 2001a, 2001b, 2004a, 2005b). The effects of PP1 inhibitors were also consistent with a direct role in channel activation. However, as modulation of phosphotyrosine levels had only minor effects on RVD, it may well be that PTK and TP address a different target, such as intermediate regulation of PP activity (Cohen 1989).

The molecular identity of the channels, whose activities are modulated by the kinase, phosphatase and cAMP mechanisms revealed by our studies remains a matter of speculation and requires further investigation. It was recently demonstrated that volumesensitive anion channels are responsible for chloride transport during sperm RVD (Petrunkina et al. 2004a, Yeung et al. 2005a). Volume-sensitive $\mathrm{Cl}^{-}$currents with similar functional properties have been reported in somatic cells (Shi et al. 2002); CLC-3 channels (voltage-gated chloride channels of the CLC family) in particular were shown to be regulated by endogenous PKC (Duan et al. 1999, Shi et al. 2002). Chloride channels have been detected in boar and human spermatozoa though not in mouse (Petrunkina et al. 2004a, Yeung et al. 2005a, 2005b). Despite apparent maintenance of RVD in salivary acinar cells isolated from mice with targeted disruption of the Clcn3 gene (Arreola et al. 2002), it has recently been shown that the properties of volume-sensitive anion channels in knockout mice are different from those in wild-type with respect to fundamental channel properties such as regulation by endogenous protein kinase $\mathrm{C}$ or differential sensitivity to blockage by anti-ClC-3 antibodies (Yamamoto-Mizuma et al. 2004). It is therefore likely that the PKC-regulated volume-sensitive anion channels playing a role in sperm RVD are indeed members of the CLC family.

As a final comment, given the potential importance of volume regulatory control, boar spermatozoa appear to be an excellent model for experimental studies. In contrast to mouse spermatozoa, boar spermatozoa show characteristics similar to human; they are available in large numbers, and, of course, are routinely obtained as ejaculated cells (as are human), whereas mouse spermatozoa are routinely obtained as epididymal cells.

\section{Acknowledgements}

The authors thank Dr J McAlister-Hermann for revision of the initial draft of this manuscript. The excellent technical assistance of Mrs E Sahin is gratefully acknowledged. This research was supported by the Deutsche Forschungsgemeinschaft (DFG) and by a postgraduate fellowship of the School of Veterinary Medicine Hannover. The authors declare that there is no conflict of interest that would prejudice the impartiality of this scientific work.

\section{References}

Arreola J, Begenisich T, Nehrke K, Nguyen HV, Park K, Richardson L, Yang B, Schutte BC, Lamb FS \& Melvin JE 2002 Secretion and cell volume regulation by salivary acinar cells from mice lacking expression of the $\mathrm{Clcn} 3 \mathrm{Cl}^{-}$channel gene. Journal of Physiology 545 207-216.

Bize I \& Dunham P 1994 Staurosporine, a protein kinase inhibitor, activates $\mathrm{K}-\mathrm{Cl}$ cotransport in LK sheep erythrocytes. American Journal of Physiology 266 C759-C770.

Brotherton J 1975 The counting and sizing of spermatozoa from ten animal species using a Coulter Counter. Andrologia 7 169-185.

Chen S, Inoue R, Inomata H \& Ito Y 1994 Role of cyclic AMP-induced $\mathrm{Cl}$ conductance in aqueous humour formation by the dog ciliary epithelium. British Journal of Pharmacology 112 1137-1145.

Cohen P 1989 The structure and regulation of protein phosphatases. Annual Review of Biochemistry 58 453-508.

Cordoba M \& Beconi MT 2001 Progesterone effect mediated by the voltage-dependent calcium channel and protein kinase $\mathrm{C}$ on noncapacitated cryopreserved bovine spermatozoa. Andrologia 33 105-112.

Crepel V, Panenka W, Kelly ME \& MacVicar BA 1998 Mitogenactivated protein and tyrosine kinases in the activation of astrocyte volume-activated chloride current. Journal of Neuroscience $\mathbf{5 2 0}$ 113-119.

Deleuze C, Duvoid A, Moos FC \& Hussy N 2000 Tyrosine phosphorylation modulates the osmosensitivity of volume-dependent taurine efflux from glial cells in the rat supraoptic nucleus. Journal of Physiology 523 291-299. 
Duan D, Cowley S, Horowitz B \& Hume JR 1999 A serine residue in CLC-3 links phosphorylation-dephosphorylation to chloride channel regulation by cell volume. Journal of General Physiology 113 57-70.

Dunham PB, Klimczak J \& Logue PJ 1993 Swelling activation of K-Cl cotransport in LK sheep erythrocytes: a three-state process. Journal of General Physiology 101 733-765.

Galindo BE, Neill AT \& Vacquier VD 2005 A new hyperpolarizationactivated, cyclic nucleotide-gated channel from sea urchin sperm flagella. Biochemical and Biophysical Research Communications 334 96-101.

Harrison RAP \& Miller NGA 2000 cAMP-dependent protein kinase control of plasma membrane lipid architecture in boar sperm. Molecular Reproduction and Development 55 220-228.

Harrison RAP \& Vickers SE 1990 Use of fluorescent probes to access membrane integrity in mammalian spermatozoa. Journal of Reproduction and Fertility 88 343-352.

Harrison RAP, Mairet B \& Miller NGA 1993 Flow cytometric studies of bicarbonate-mediated $\mathrm{Ca}^{2+}$ influx in boar sperm populations. Molecular Reproduction and Development 35 197-208.

Hoffmann EK 2000 Intracellular signalling involved in volume regulatory decrease. Cellular Physiology and Biochemistry 10 273-288.

Hougaard C, Klaerke DA, Hoffmann EK, Olesen SP \& Jorgensen NK 2004 Modulation of KCNQ4 channel activity by changes in cell volume. Biochimica et Biophysica Acta 1660 1-6.

Hubert EM, Musch MW \& Goldstein L 2000 Inhibition of volumestimulated taurine efflux and tyrosine kinase activity in the skate red blood cells. Pflügers Archiv 440 132-139.

Johnson LA, Aalbers JG \& Grooten HJG 1988 Artificial insemination of swine: fecundity of boar semen stored in Beltsville TS (BTS). Modified Modena (MM), or MR-A and inseminated on one, three and four days after collection. Zuchthygiene 23 49-55.

Khalil AAY, Petrunkina AM, Sahin E, Waberski D \& Töpfer-Petersen E 2006 Enhanced binding of sperm with superior volume regulation to oviductal epithelium. Journal of Andrology 27 754-765.

Klein JD, Perry PB \& O' Neill WC 1993 Regulation by cell volume of $\mathrm{Na}^{+}-\mathrm{K}^{+}-2 \mathrm{Cl}^{-}$cotransport in vascular endothelial cells: role of protein phosphorylation. Journal of Membrane Biology 132 243-252.

Kulkarni SB, Sauna ZE, Somlata V \& Sitaramam V 1997 Volume regulation of spermatozoa by quinine-sensitive channels. Molecular Reproduction and Development 46 535-550.

Lang F, Busch GL, Ritter M, Völkl H, Waldegger S, Gulbins E \& Häussinger D 1998 Functional significance of cell volume regulatory mechanisms. Physiological Reviews 78 247-306.

Larsen AK, Jensen BS \& Hoffmann EK 1994 Activation of protein kinase $C$ during cell volume regulation in Ehrlich mouse ascites tumor cells. Biochimica et Biophysica Acta 1222 477-482.

Leclerc P \& Kopf GS 1995 Mouse sperm adenylyl cyclase: general properties and regulation by the zona pellucida. Biology of Reproduction 52 1227-1233.

Leclerc P, de Lamirande E \& Cagnon C 1996 Cyclic adenosine 3',5' monophosphate-dependent regulation of protein tyrosine phosphorylation in relation to human sperm capacitation and motility. Biology of Reproduction 55 684-692.

Lepple-Wienhues A, Szabo I, Wieland U, Heil L, Gulbins E \& Lang F 2000 Tyrosine kinases open lymphocyte chloride channels. Cellular Physiology and Biochemistry 10 307-312.

Liu DY \& Baker HW 1997 Protein kinase C plays an important role in the human zona pellucida-induced acrosome reaction. Molecular Human Reproduction 3 1037-1043.

MacLeod RJ, Lembessis P \& Hamilton JR 1994 Isotonic volume reduction associated with cAMP stimulation of $36 \mathrm{Cl}$ efflux from jejunal crypt epithelial cells. American Journal of Physiology 267 G387-G392.

Musch MW, Davis-Amaral EM, Leibowitz KL \& Goldstein L 1998 Hypotonic-stimulated taurine efflux in skate erythrocytes: regulation by tyrosine phosphatase activity. American Journal of Physiology 274 R1677-RR186.
O'Donnell J 1969 Electronic counting and sizing of mammalian spermatozoa and cytoplasmic droplets. Journal of Reproduction and Fertility 19 263-272.

Petrunkina AM \& Töpfer-Petersen E 2000 Heterogeneous osmotic behaviour in boar sperm populations and its relevance for detection of plasma membrane changes. Reproduction, Fertility, Development 12 297-305.

Petrunkina AM, Harrison RAP, Hebel $M$, Weitze KF \& TöpferPetersen E 2001a Role of quinine sensitive channels in boar and bull sperm volume regulation. Reproduction 122 327-336.

Petrunkina AM, Petzoldt R, Stahlberg S, Pfeilsticker J, Beyerbach M, Bader H \& Töpfer-Petersen E 2001b Sperm cells volumetric measurements as parameters in bull semen function evaluation: correlation with non-return rate. Andrologia 33 360-367.

Petrunkina AM, Harrison RAP, Ekhlasi-Hundrieser $M$ \& TöpferPetersen E 2004a The role of volume-sensitive osmolyte and anion channels in volume regulation by mammalian spermatozoa. Molecular Human Reproduction 10 815-823.

Petrunkina AM, Radcke S, Günzel-Apel A-R, Harrison RAP \& TöpferPetersen E 2004b Role of potassium channels, the sodiumpotassium pump and the cytoskeleton in the control of dog sperm volume. Theriogenology 61 35-54.

Petrunkina AM, Hebel M, Waberski D, Weitze KF \& Töpfer-Petersen E $2004 c$ Requirement of intact cytoskeleton for volume regulation in boar spermatozoa. Reproduction 127 105-116.

Petrunkina AM, Gröpper B, Töpfer-Petersen E \& Günzel-Apel A-R 2005 a Volume regulatory function and sperm membrane dynamics as parameters for evaluating cryoprotective efficiency of a freezing extender. Theriogenology 63 1390-1406.

Petrunkina AM, Jebe E \& Töpfer-Petersen E 2005b Regulatory and necrotic volume increase in boar spermatozoa. Journal of Cell Physiology 204 508-521.

Robson L \& Hunter M 1994 Role of cell volume and protein kinase C in regulation of a $\mathrm{Cl}$ conductance in single proximal tubule cells of Rana temporaria. Journal of Physiology 480 1-7.

Robson L \& Hunter M 1997 Regulation of an outwardly rectifying $\mathrm{Cl}$ conductance in single proximal tubule cells isolated from frog kidney. Journal of Physiology 498 409-417.

Shi C, Barnes S, Coca-Prados M \& Kelly ME 2002 Protein tyrosine kinase and protein phosphatase signaling pathways regulate volumesensitive chloride currents in a nonpigmented ciliary epithelial cell line. Investigative Ophthalmology and Visual Science 43 1525-1532.

Smith GD, Wolf DP, Trautman KC, da Cruz e Silva EF, Greengard P \& Vijayaraghavan S 1996 Primate sperm contain protein phosphatase 1, a biochemical mediator of motility. Biology of Reproduction 54 719-727.

Thoroed SM, Bryan Sisneros A \& Doroshenko P 1999 Protein phosphotyrosine phosphatase inhibitors suppress regulatory volume decrease and the volume-sensitive $\mathrm{Cl}$ conductance in mouse fibroblasts. Pflügers Archiv 438 133-140.

Tilly BC, Bezstarosti K, Boomaars WE, Marino CR, Lamers JM \& de Jonge HR 1996 Expression and regulation of chloride channels in neonatal rat cardiomyocytes. Molecular and Cellular Biochemistry 157 129-135.

Voets T, Manolopoulos V, Eggermont J, Ellory C, Droogmans G \& Nilius B 1998 Regulation of a swelling-activated chloride current in bovine endothelium by protein tyrosine phosphorylation and $G$ proteins. Journal of Physiology 506 341-352.

Waberski D, Meding S, Dirksen G, Weitze KF, Leiding C \& Hahn R 1994 Fertility of long term stored boar semen: influence of extender (Androhep and Kiev), storage time and plasma droplets in the semen. Animal Reproduction Science 36 145-151.

Weitze KF 2001 Spermatologische Untersuchung. In Veterinärmedizinische Andrologie, pp 67-82. Eds W Busch \& A Holzmann. Stuttgart: Schattauer.

Yamamoto-Mizuma S, Wang GX, Liu LL, Schegg K, Hatton WJ, Duan D, Horowitz TL, Lamb FS \& Hume JR 2004 Altered properties of volume-sensitive osmolyte and anion channels (VSOACs) and 
membrane protein expression in cardiac and smooth muscle myocytes from Clcn3-/- mice. Journal of Physiology $\mathbf{5 5 7}$ 439-456.

Yeung CH, Sonnenberg-Riethmacher E \& Cooper TG 1999 Infertile spermatozoa of c-ros tyrosine kinase receptor knockout mice show flagellar angulation and maturational defects in cell volume regulatory mechanisms. Biology of Reproduction 61 1062-1069.

Yeung CH, Wagenfeld A, Nieschlag E \& Cooper TG 2000 The cause of infertility of male c-ros tyrosine kinase receptor knockout mice. Biology of Reproduction 63 612-618.

Yeung CH, Anapolski M, Depenbusch M, Zitzmann M \& Cooper TG 2003 Human sperm volume regulation. Response to physiological changes in osmolality, channel blockers and potential sperm osmolytes. Human Reproduction 18 1029-1036.

Yeung CH, Anapolski M, Setiawan I, Lang F \& Cooper TG 2004a Effects of putative epididymal osmolytes on sperm volume regulation of fertile and infertile c-ros transgenic mice. Journal of Andrology 25 216-223.

Yeung CH, Breton S, Setiawan I, Xu Y, Lang F \& Cooper TG 2004b Increased luminal $\mathrm{pH}$ in the epididymis of infertile c-ros knockout mice and the expression of sodium-hydrogen exchangers and vacuolar proton pump $\mathrm{H}+$-ATPase. Molecular Reproduction and Development 68 159-168.

Yeung CH, Barfield JP \& Cooper TG 2005a The role of anion channels and $\mathrm{Ca}^{2+}$ in addition to $\mathrm{K}^{+}$channels in the physiological volume regulation of murine spermatozoa. Molecular Reproduction and Development 71 368-379.

Yeung CH, Barfield JP \& Cooper TG 2005b Chloride channels in physiological volume regulation of human spermatozoa. Biology of Reproduction 73 1057-1063.

Received 9 February 2006

First decision 11 April 2006

Revised manuscript received 26 May 2006

Accepted 11 October 2006 